\section{colunn}

JACQUELINE BUTTI COMBINEERT PEDAGOGIEK MET MEDIA. ZE WERKT AL 30 JAAR ALS PM-ER BIJ KOREIN, STUDEERDE AF ALS ORTHOPEDAGOGE EN IS PROGRAMMAMAKER RADIO IN EINDHOVEN.

\title{
Softie of hardliner?
}

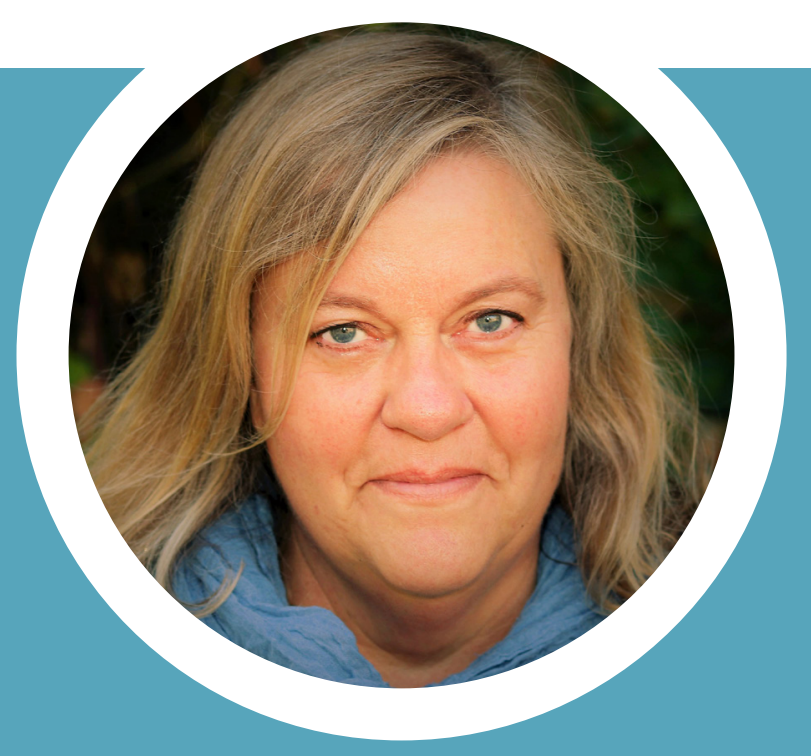

In deze samenleving is zelfredzaamheid het belangrijkste doel. Daar beginnen we in de opvoeding zo snel mogelijk mee. Een baby die zelf een flesje kan vasthouden, en weer iets later een stukje brood. Onderling kunnen er aanzienlijke verschillen zijn, afhankelijk van de capaciteiten van het kind en de stimulans die ouders en andere verzorgers geven. 'Het is zo'n lief kindje... daar doe je toch de sandaaltjes even van vast?' Nee! Laat het gerust maar experimenteren met die lastige bandjes. Kinderen vinden dat helemaal niet erg, totdat de volwassene er tijdsdruk op zet. Dan krijg je heibel, want 'zelf doen' vindt bijna elk kind leuk.

Als pm'ers proberen wij dat proces van zelfstandig worden zorgvuldig te begeleiden. Maar er leiden meerdere wegen naar Rome, dus verschillen mensen van aanpak. Je hebt de 'hardliners' en de 'softies'. Ik chargeer even.

Elze van vier loopt met een dramatisch verdrietig gezichtje (zonder een traan) naar de pm'er en laat haar vuile en beetje rode knietje zien. Gevallen. 'Kom op, er is niks aan de hand, ga maar weer spelen'! zegt de pm'er die het belangrijk vindt dat het kind ook met kleine tegenslagen leert omgaan. Met een verongelijkt gezichtje draait Elze zich om, nog wat theatraal nahinkend en teleurgesteld. Deze pm'er bedient zich van de daar-word-je-flink-van-tactiek. Het resultaat is dat Elze alweer aan het spelen is, zelfs met

\section{'Flink zijn vind ik niet zo} belangrijk' 'het been'. Goed geslaagd zou je zeggen. Toch is het niet mijn aanpak. Ik ben een softie!

Een kind dat met een probleem naar je toekomt dat je zelf niet als probleem ziet, heeft toch een vraag naar aandacht. 'Het been' verdient aandacht - maar vooral de eigenares

ervan. Het kind checkt naar mijn idee de veiligheid. Het vangnet: is dat er nog? Het vangnet is de basis om meer aan te kunnen en aan te durven. Daar is niks softs aan! 'Hé Elze, wat kijk je verdrietig... Wat is er?' (Even een arm om haar heen en op m'n hurken gaan zitten). 'Gevallen? Daar schrik je van, hè? Wat zou helpen voor je knie? Een nat doekje?' En weg is ze weer... Nog even een blik met een glimlach over haar schoudertje.

Ik kies dus voor een empatische toon in plaats van de 'kom-op'-klank. Flink zijn vind ik niet zo belangrijk. Wel wil ik kinderen leren nadenken over hoe ze hun eigen lichaam kunnen verzorgen bij kleine wondjes zoals in deze situatie. Daarmee kunnen ze ook zichzelf rust (dus troost) geven.

Kortom, zelfs kinderen die zich zogenaamd aanstellen zie ik niet als aanstellers. Ik wil tegemoet komen aan de emotionele behoefte van het kind op dat moment. Dat schept meteen een mogelijkheid om een kind wat te leren over zichzelf. En als hetzelfde kind vier keer achter elkaar komt met hele kleine onduidelijke klachten? Ook dan blijf ik reageren, want dan is er mogelijk iets anders aan de hand wat ik eerder over het hoofd heb gezien. < 